\title{
A SURVEY PAPER ON FACTORS CONTROLLING THE ENERGY ABSORPTION OF CRASH BOX
}

\author{
Ashutosh S. Kalshetti ${ }^{1}$, Sanjaysingh Vijaysingh Patil ${ }^{2}$ \\ ${ }^{l}$ ME Student, Department of Mechanical Engineering RMD Sinhgad School of Engineering (RMDSSOE) Warje Pune, \\ India \\ ashutosh.kalshetti5@gmail.com \\ ${ }^{2}$ Associate professor, Department of Mechanical Engineering RMD Sinhgad School of Engineering (RMDSSOE) \\ Warje Pune, India \\ sanjaysingh.patil@sinhgad.edu
}

\begin{abstract}
Thin-walled tubular Crash box are extensively used as energy absorbers in numerous automotive and aerospace applications as a result of their higher energy absorption capacity. In past lot of research has been done on crash tubes. Crash box of various cross section/shape and materials have been analyzed. Some researchers have done quasi-static analysis whereas some have gone for dynamic analysis. Just in case of energy absorption through dynamic impact, Speed of impact \& momentum of impact are influential factors. The dimensions viz. lengths, width, wall thickness, material, and loading conditions were also varied. Crash box with metallic/structural foam filling, multi-cell or tapered crash boxes have also been studied for axial or oblique loading conditions. Some researchers have used finite element based software's for their study while others used experimental method. Review of all the above factors \& their effect on energy absorption capability of tubes is taken into account during this paper, based on which the parameters will be selected for further research.
\end{abstract}

Keywords: Crash Box, Energy Absorption, Impact, Thin-Walled.

\section{INTRODUCTION}

Crash box, mounted at the front end of the front sub frame and on rear side of vehicle, is one of the major automotive parts in dissipating the initial crash energy. They are made largely from metal components. In case of frontal crash accident, crash box is expected to collapse and absorbing crash energy prior to the other body parts so that damage to the body in white parts/occupant cabin is minimized. The axial folding/deformation of metal tubes has been known as best energy absorbing mechanism. Thin-walled Crash box have been widely employed in crash-worthiness applications for automobile to safeguard occupant/passenger from injuries/fatality, and also largely used as kinetic energy absorbers for their robustness, high energy absorption performance and weight efficiency [16-17].

Energy absorbers have been designed which dissipate energy owing to friction, fracture, metalcutting, torsion, crushing, cyclic plastic deformation, shear, extrusion and fluid flow. Among all the above factors cyclic plastic deformation, extrusions, and friction are among primary energy absorbing mechanism. Many energy absorbing devices are mainly dependent on more than one energy absorbing mechanism but general, cyclic plastic deformations widely used for energy absorption.

Thin-walled crash box structures are widely used in engineering applications due to their efficient load carrying capability relative to material volume i.e. specific energy absorption.
Over the past decades, substantial efforts have been made in investigation of axial crushing behaviors of the thin-walled crash box by using analytical and experimental methods. For example, Alexander first derived an analytical solution to calculate the axial mean crushing force for circular tubes [18].Formulas to calculate axial crush response of aluminum crash box where proposed byWierzbicki [19]and Abramowicz [20]. The analytical predictions were validated experimentally by Abramowicz [21] and Jones, and Langseth and Hopperstad [22].

Previous studies have primarily focused on investigating of energy absorption of thin-walled crash box under axial loading and also stated that axial crushing of tubes have comparatively high energy absorbing capacity.

The objective of this paper/study is to provide an overview in the field of energy absorbers/crash box that are used to mitigate impact collisions. Work published by researchers and engineers over the years related to tubular structures as energy absorbers are highlighted. This article will highlight the analysis and findings associated with tubes as impact energy absorbers.

\subsection{General Characteristic For Energy Absorption}

\section{Structure}

Fig.1 indicates a typical Load-Displacement curve where area under the curve shows the amount of energy absorbed during impact. Fig. 2 shows the folding of tubes during the impact. 


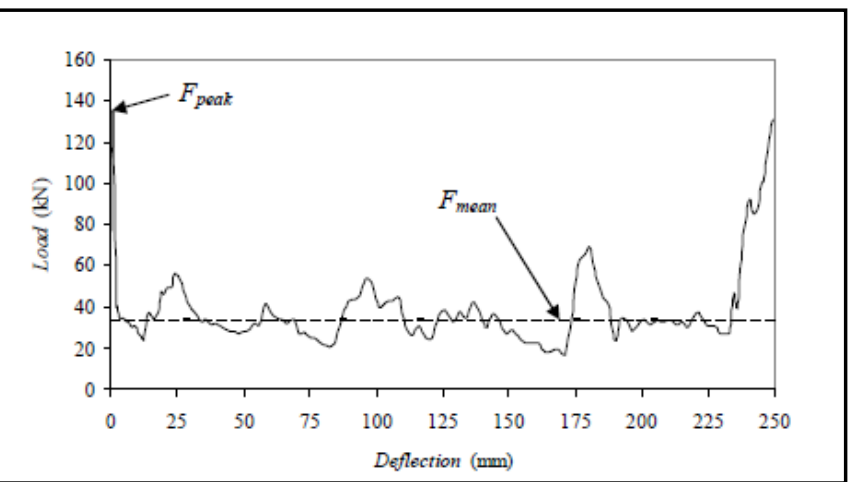

Fig. 1. Typical Load-Displacement Curve [1]

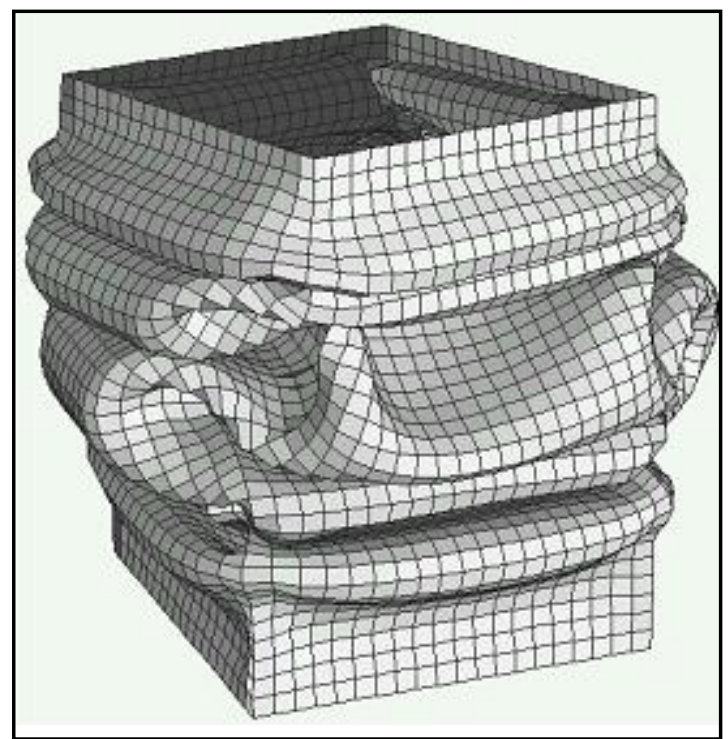

Fig. 2. Folding of tubes during impact [2]

\subsection{Fundamental of Energy Absorption}

Terms widely used to calculate and quantify the crashworthiness thin-walled crash box areEnergy absorption (EA), Specific Energy Absorption (SEA), Mean Crushing Load(MCL), the Peak Force (PCF) and Crash Load Efficiency (CFE) Taking an axial crushing of crash box for calculation, the energy absorption isintegration of the crushing force with respect to displacement $\mathrm{x}$ as below

$E(L)=\int F(X) d x$

Where $\mathrm{L}$ denotes deformed length and $\mathrm{F}$ is the axial crushing force. A practical force V/s deformation curve of a crash box is illustrated in Fig. 1. Mean load is an appropriate criterion to find the energy absorption capacity of an absorber. It is obtained by dividing the measured absorbed energy to the total crushing distance

$\mathrm{P}_{\text {mean }}=\frac{1}{\delta} \int \mathrm{P} \mathrm{d} \delta$

The specific energy absorption (SEA) is the ratio of energy absorbed to the structural mass $\mathrm{M}$ is morespecific criterion to measure energy absorption capability of crash box per unit mass, higher SEA numbers indicates higher capacity of energy absorption per unit mass
$\mathrm{SEA}=($ Etotal $/ \mathrm{M})$

Crush force efficiency is defined as ratio of mean crushing force to maximum crushing load.

Crush force efficiency $(\mathrm{CFE})=\mathrm{P}_{\text {mean }} / \mathrm{P}_{\max }$

Maximum the crush force efficiency for energy absorbers used in crash worthiness design when the protection of occupants is a priority.

\section{REVIEW ON VARIOUS FACTORS} AFFECTING ENERGY ABSORTIN OF CRUSH BOX

Factors that have significant influence on the energy absorption such as shapes of tubes, materials, method of analysis, angle of impact, velocity of impactor, most important thickness of the tube and cross-sectional width of the tube etc. are listed in below Table. In Table 1.1, Ref. No. indicates serial number from the list of references referred at the end of the paper.

\subsection{Material of Crash Box}

Crash box material plays critical role in selection of a material for crash energy absorption. Performance of crash box during crash will determine the injury level of the occupants. A crash-worthy material should absorb the kinetic energy of the impacting vehicle and also prevent the transfer of peak loads to the occupant cell. Use of appropriate material, geometrical shape and features has potential for major payoffs such as lower weight, design of higher stiffness areas which is stable energy absorption processes.

Much research have studied either aluminum/aluminum alloy $[1,3,4,5,6,8,10,11,13]$ or steel $[1,2,7,9,14,15]$. Other materials like Glass Reinforced Composite, Kevlar Reinforced Composite have also been studied by some researchers [2]. Also foam filled aluminum is taken for study [8]. Foams are used to improve energy absorption of the thin-walled crash box without increasing volume and weight too much, materials such as honeycombs and metal foams are often used as fillers for such structures. Filling of the column with moderate or high strength aluminum foam gives better Specific Energy Absorption (SEA, absorbed energy per unit mass) .Under certain circumstances Foamfiller could leads to lower energy absorption capacity of unit structural mass.

Aluminum alloy studied are of different types. The heat treatment followed for this material is different. Aluminum on the other hand is increasingly gaining ground as the choice material for automotive body in white and chassis parts since it is light weight, with better strength properties on a weight basis as compared to steel, and also easy to recycle. As compared to steel, aluminum/ aluminum alloy have low density; hence it is widely used in light weight applications. 
When the study was carried out to compare energy absorption per unit weight of different cross sectional tubes with same cross section area, it was found that amount of energy absorption steel is 4.5 times that of aluminum [1].The maximum load carrying capacity and energy absorbing capacity of the steel tubes were higher than those of the reinforced and Composite tubes due to high strength rigidity of steel [2].Energy absorbing capacity of steel tubes is 2 to 3 times higher than that of composite tubes [2].

\begin{tabular}{|c|c|c|c|c|c|c|c|}
\hline $\begin{array}{l}\text { Ref. } \\
\text { No. }\end{array}$ & Material of tube & Shape of tube & $\begin{array}{l}\text { Analysis } \\
\text { Method- } \\
\text { Quasi-static/ } \\
\text { Dynamic }\end{array}$ & $\begin{array}{l}\text { Impact } \\
\text { Velocity }\end{array}$ & $\begin{array}{l}\text { Angle of } \\
\text { Impact }\end{array}$ & $\begin{array}{l}\text { Thickness } \\
\text { of tube } \\
(\mathrm{mm})\end{array}$ & $\begin{array}{l}\text { Width of tube } \\
(\mathrm{mm})\end{array}$ \\
\hline 1 & Steel, Aluminum & $\begin{array}{l}\text { Square, Circler } \\
\text { Ellipses }\end{array}$ & Dynamic & $\begin{array}{l}33.825 \\
\mathrm{~km} / \mathrm{hr} .\end{array}$ & -- & $1.25,1.5$ & $\begin{array}{l}\text { Side- 30, Side- } \\
50\end{array}$ \\
\hline 2 & $\begin{array}{l}\text { Mild Steel, Glass } \\
\text { Reinforced Composite } \\
\text { \& Kevlar Reinforced } \\
\text { Composite }\end{array}$ & Square & Quasi-static & $10 \mathrm{~mm} / \mathrm{min}$ & -- & 1 & 100 \\
\hline 3 & Aluminum alloy & Square & Dynamic & $\begin{array}{l}18.792 \text { to } \\
25.812 \\
\mathrm{~km} / \mathrm{hr} .\end{array}$ & -- & 1.25 & 44.3 \\
\hline 4 & Aluminum & Square & Quasi-static & $80 \mathrm{~mm} / \mathrm{min}$ & $7,14,21$ & 1.5 & 35 \\
\hline 5 & Aluminum alloy & Circle & Quasi-static & $5 \mathrm{~mm} / \mathrm{min}$ & -- & 1.3 & OD-50.5 \\
\hline 6 & Aluminum alloy & $\begin{array}{l}\text { Square (Tapered } \\
\text { \& straight) }\end{array}$ & Dynamic & $36 \mathrm{~km} / \mathrm{hr}$. & $\begin{array}{l}0 \text { to } 40 \text { in } \\
\text { step of } 5\end{array}$ & 2 & 80 \\
\hline 7 & High strength steel & Circle & Dynamic & $\begin{array}{l}19.2 \text { to } 88.16 \\
\mathrm{~km} / \mathrm{hr} \text {. }\end{array}$ & -- & 0.5 to 1 & Dia. 31 to 62 \\
\hline 8 & $\begin{array}{l}\text { Aluminum alloy \& Al- } \\
\text { Foam filled. }\end{array}$ & Square & Dynamic & $36 \mathrm{~km} / \mathrm{hr}$. & $0-10-20-30$ & 1.4 to 3 & 64 to 98 \\
\hline 9 & Annealed M.S & Square & Dynamic & $36 \mathrm{~km} / \mathrm{hr}$. & $0-10-20-30$ & 1.2 to 3 & 80 \\
\hline 10 & Aluminum alloy & Square & Quasi-static & $700 \mathrm{~mm} / \mathrm{hr}$. & $5,15,30$ & $1.9,2.46$ & Side- 80 \\
\hline 11 & Aluminum alloy & Circle & Quasi-static & $10 \mathrm{~mm} / \mathrm{min}$ & -- & $0.8,1,1.2$ & ID-30, 39,44 \\
\hline 12 & Steel & $\begin{array}{l}\text { Square, Rectangle, } \\
\text { Circle, Hexagon, } \\
\text { Octagon }\end{array}$ & Dynamic & $56 \mathrm{~km} / \mathrm{hr}$. & $0,15,30$ & 2 & $\begin{array}{l}75,60 / 90,95 \\
\text { Dia. } 50 \text { Side } \\
\text { 45/30 Side } \\
\end{array}$ \\
\hline 13 & Aluminum alloy & Rectangle & $\begin{array}{l}\text { Quasi-static } \\
\text { \& Dynamic }\end{array}$ & $54 \mathrm{~km} / \mathrm{hr}$. & $\begin{array}{l}0-10-15- \\
20-25-30- \\
35-40\end{array}$ & $1.5,2,2.5$ & $\begin{array}{l}60 \times 10080 \\
\times 100100 \times 100\end{array}$ \\
\hline 14 & Steel & Octagon & Dynamic & $3.6 \mathrm{~km} / \mathrm{hr}$. & -- & 1.52 & Side 31.8 \\
\hline 15 & Steel & Square & $\begin{array}{l}\text { Quasi-static } \\
\text { \& Dynamic }\end{array}$ & $\begin{array}{l}18 \mathrm{~km} / \mathrm{hr} \text {. to } \\
270 \mathrm{~km} / \mathrm{hr} \text {. }\end{array}$ & -- & $1.25,1.5$ & 30,50 \\
\hline
\end{tabular}

\subsection{Shape of Crash Box}

There have been several studies in the literature reporting on the considerable effect of energy absorption between various section shapes. Different shapes of tubes which have been used for the study of energy absorption. The cross sectional shapes of the tubes are Square, Rectangle, Circle, Hexagon, Octagon.

Most of the research is based on the square tubes [1- 4, 6, 8, $9,10,12,15]$. Circular profile is also studied by many scientists as this is one of the most standard shapes $[1,5,7$, 11, 12]. Elliptical shape is also considered for energy absorption [1]. Hexagonal shape is also taken into consideration for this [12]. Another shape octagon is studied by few researchers $[12,14]$.

By keeping constant thickness and same perimeter, significantly lower energy absorption is found in square and rectangular profile when compared with circular, hexagon and octagon profile at the time of axial crushing [20]. The octagonal profile absorbs slightly more energy during deformation than circular and the hexagonal profiles, which absorb nearly the same amount of energy.

There are very few researchers who have studied behavior of tubes of different shapes at one time \& have done the comparison of energy absorption capabilities of these tubes either keeping the perimeter of the tube same or same area of cross-section. Some people have gone for tapered tubes or frusta instead of straight tubes. They have also done the comparison of the straight $\&$ tapered tubes.

Energy absorption decreases if the load direction is increased from 0 to 30 degree. Rectangular profiles have less sensitive for variation in the load direction.

Multi cells thin-walled crash box have good weight efficiency with desirable energy absorption. The energy absorption efficiency of multi-cell columns is on 50\%$100 \%$ higher side than that of foam-filled columns. By 
introducing more corners into the structure, the energy absorption of thin-walled tubes can be further increased. If the cross sectional area is kept same, the ellipse-cross section had more energy absorption than the square \& circular tubes [1].

\subsection{Type of Analysis}

Quasi-static and dynamic analysis, are two types of analysis which are widely used to study the crushing behavior, mode of crush, and calculation of the energy absorber. Quasi-static analysis of tubes is preferred by some researcher $[2,4,5,10,11,13,15]$ while others have opted for dynamic analysis $[1,3,6,7,8,9,12,13,14,15]$. However loading in realworld accidental case is primarily dynamic or impulsive in nature [13]. Software is used for analysis in many cases [1, $3,6-10,13,14,15]$. Some are using ABAQUS [3, 9, 13, 15], while other researchers have used LS-DYNA [6, 7, 10, 14]. Some have used ANSYS-LS-DYNA [1, 8] and one researcher has used PAM-CRASH [12]. Few researchers have used both experimental and software, rest have compared there results with experimental results published by earlier researchers.

In quasi-static, at very low speed behavior of the crash box becomes symmetric or asymmetric. Due to low speed, peak load becomes less and deflection becomes high. From literature survey it is found that there are different quasistatic speed were applied for the crushing of the tubes such that $5 \mathrm{~mm} / \mathrm{min}, 8 \mathrm{~mm} / \mathrm{min}$ and $10 \mathrm{~mm} / \mathrm{min}$

In real world accidents generally occur at high velocities like 10,15 and $20 \mathrm{~m} / \mathrm{s}$ i.e. dynamic loading. In dynamic impact, maximum force is required for the folding of the first lobe after that load becomes decreases. Peak load becomes high in dynamic analysis as compared to quasistatic analysis. Crushing behavior of the tube depends up on impact of loading such as axially or oblique impact. Deformation in dynamic analysis is less as compared to quasi-static analysis it may be due to strain rate hardening or inertia effect.

\subsection{Impact Velocity}

For studying dynamic impact cases velocity of impact is varying widely. The impact velocity has a limitation of experimental facility; the impact velocity was not higher than $10 \mathrm{~m} / \mathrm{s}$ [3]. But maximum of all frontal collisions take place at speeds up to $56 \mathrm{~km} / \mathrm{hr}$. [12]. Few researchers have used the impact velocity range from 5 to $20 \mathrm{~km} / \mathrm{hr}$., with some increment value, to represent the range of low speed impacts using which vehicle crash box are designed [13].

\subsection{Angle of Impact}

Axial crushing of thin-walled crash box is one of the most desirable failure modes since it has a comparatively high energy absorbing capacity. During actual crash event, the energy absorber is rarely subjected to pure axial crushing, rather it's a combination of the two modes axial and bending collapse. If the crash box experiences global bending instead of axial crushing, the energy absorption is lower, and both moments and axial forces are transferred to the rest of the structure.

Some researchers have studied the axial crushing of the columns [1, 2,3,5,7, 11, 14, 15]. But oblique impacts are much more common in real crash events [8]. Oblique loading is considered by some researchers $[4,6,8,9,10$, 13]. Despite extensive research on axial crushing, crash box in real crash scenarios are usually subjected to oblique loading, i.e. the impact is not in the direction of axis of rash box. Research in this area is relatively limited. [9] Energy absorption drops drastically when global bending mode is initiated instead of progressive buckling, and it decreases further with increasing load angle. Mean load also decreases with increasing load angle. With increase in load angle, peak crushing force (PCF) also decreases[6].The automotive industry requires bumper system which must crush and absorb load within an angle of 20-30 degrees to the centerline axis or crash box.

\subsection{Effect of Wall Thickness}

With increase in wall thickness energy absorption also increases $[1,2,8,10]$. There is subsequent increase in energy absorption of crash box with increasing the thickness of the wall, because it has more material to deform plastically. Hence, the energy absorption of a crash box if length is kept constant increases with increase in the wall thickness [13]. Referring the mean force formula, we can say that width and thickness of crash box are the most influential factor is energy absorption. Thickness affects energy absorbing efficiency more strongly [7]. The down gaging of wall thickness also helps to reduce the peak crushing force because it leads to decrees of stiffness [6].

Wierzbicki \& Abramowicz analyzed the crushing of thinwalled multi-corner structure [20]. Mean crushing load for the symmetrical Crushing for square tube crash box under axial loading made of rigid-plastic material is given by,

$\mathrm{Pm}=9.56 \times \sigma 0 \times \mathrm{t} 5 / 3 \times \mathrm{W} 1 / 3$

Wheret is the crash box thickness, $\sigma 0$ is yield stress, $\mathrm{W}$ is width of the square crash box\&. For an arbitrary angle between the adjacent faces of the crash box.

Wierzbicki \& Abramowicz[20] further providedan improved model to predict mean crushing load previously defined for the average static crushing force for asymmetric collapse of a square tube crash box to as,

$\mathrm{Pm}=13.06 \times \sigma 0 \times \mathrm{t} 5 / 3 \times \mathrm{W} 1 / 3$.

Referring above equation of mean crushing load calculation for rectangular tubes crash box states that energy absorption per unit mass increases with increasing wall thickness. 


\subsection{Effect of Width of Tube}

The response of energy absorbers is majorly influenced by their geometry parameters, such as cross-sectional dimensions [13]. With increasing width of crash box more material is available per fold for deformation and hence energy absorption also goes up. Also increasing the width of the crash box leads to increase the crushing load, since large impact loads are required to compress high gauge crash box and which results in decreasing the number of tube folds in plastic deformation $[1,15]$. The same is also evident from the above formula derived by Abramowicz. Increase in wall thickness also implies higher crash box mass and thus reduces specific energy absorption [8]. The profiles with large wall thickness and small profile width give a low relative fluctuation of the crushing force (i.e. a more stable folding process), while profiles with small wall thickness and large profile width give a large relative fluctuation of the crushing force (i.e. a less stable folding process) [12]

\section{FINDING FROM LITERATURE REVIEW}

Different types of energy absorbing tubes (square, rectangular, elliptical etc.) have been studied in past. The study is done for quasi-static or dynamic condition. Different materials used for tubes are aluminum alloy, steel and composite materials etc. Aluminum absorbs more energy per unit weight as compared to steel. For most profiles with load direction variations the energy absorption decreases. Only the rectangular profile especially in a lying orientation is significantly less sensitive for variations in the load direction. Foam filled tubes also used for energy absorption but weight is more as compared to empty cross section tubes. Energy absorption increases with increase in the width and thickness of the tube.

In general most research is based on only an axial loading and uniform thickness cross-sections. For oblique load directions and varying thickness too little results have been published. As in real vehicle collisions the two longitudinal members (crash box) often are not loaded in a synchronous fashion and also not loaded pure axially i.e. more realistic load cases are with an angle of incidence. As very less work is done related to varying thickness rectangular tube.

\section{CONCLUSIONS}

Crash box play an important role in energy absorption in slow speed or high speed impact. This paper presents an inclusive review on the effect of energy absorption due to various factors. Most research is done on aluminum, aluminum alloy or steel material which states that energy absorption of Steel is higher as compared to aluminum. Rectangular \& square tubes have better energy absorb in oblique loading that compared to other shaped tubes. In carrying out Dynamic-experimental analysis parameters like mass of impact \& velocity of impact are having limitations. References shows that the multi cell thin-walled have better performance in terms of energy absorption compare with single thin-walled crash box. In general most research is based on only an axial loading and uniform thickness cross- sections. For oblique load directions and varying thickness crash box too little results have been published. Thus there is a need of studying the effect of varying thickness section crash box during oblique loading.

\section{REFERENCES}

[1] Javad Marzbanrad, Mehdi Mehdikhanlo , Ashkan Saeedi Pour, An energy absorption comparison of square, circular, and elliptic steel and aluminum tubes under impact loading, Turkish J.Eng.Env.Sci.33 (2009) , $159-166$.

[2] A.M.S. Hamouda R.O. Saied, F.M. Shuaeib, Energy absorption capacities of square tubular structures, Journal of Achievements in Materials and Manufacturing Engineering, Vol. 24, Issue 1, 2007

[3] X.W. Zhang, H. Su, T.X. Yu, Energy absorption of an axially crushed square tube with a buckling initiator, International Journal of Impact Engg-36, 2009, 402417

[4] A. Alavi Nia, Kh. Fallah Nejad, H. Badnava, H.R. Farhoudi, Effects of buckling initiators on mechanical behavior of thin-walled square tubes subjected to oblique loading, Thin Walled Structures-59, 2012, 8796

[5] X.W. Zhang, Q.D. Tian, T.X. Yu, Axial crushing of circular tubes with buckling initiators, Thin Walled Structures-47, 2009, 788-797

[6] Chang Qi, Shu Yang, Fangliang Dong, Crushing analysis and multiobjective crashworthiness optimization of tapered square tubes under oblique impact loading, Thin Walled Structures, 59, 2012, 103 119

[7] Y.S. Tai, M.Y. Huang, H.T. Hu, Axial compression and energy absorption characteristics of high-strength thin-walled cylinders under impact load, Theoretical and Applied Fracture Mechanics 53 (2010) 1-8

[8] Shu Yang, Chang Qi, Multiobjective optimization for empty and foam-filled square columns under oblique impact loading, International Journal of Impact Engineering-54, 2013, 177-191

[9] Jie Song, Fenglin Guo, A comparative study on the windowed and multi-cell square tubes under axial and oblique loading, Thin Walled Structures-66, 2013, 9-14

[10] A. Reyes, M. Langseth, O.S. Hopperstad, Crashworthiness of aluminum extrusions subjected to oblique loading: experiments and numerical analyses, International Journal of Mechanical Sciences 44 (2002) 1965-1984

[11] S.-K. Kim, K.-H.I, C.-S. Hwang, I.-Y. Yang A Study on Experimental Characteristics Of Energy Absorption Control In Thin-Walled Tubes For The Use of Vehicular-Structure Members, International Journal of Automotive Technology, Vol. 3, No. 4, 2002, 137-145

[12] W.J. Witteman, Improved Vehicle Crashworthiness Design by Control of the Energy Absorption for Different Collision Situations, Doctoral dissertation, Eindhoven University of Technology, Netherlands, 1999 
[13] Gregory Nagel, Impact \& energy absorption of straight $\&$ tapered rectangular tubes, Ph.D. Thesis, Queensland University of Technology, 2005

[14] Yucheng Liu, Michael L. Day, Simplified Modeling of Thin-Walled Tubes with Octagonal Cross Section Axial Crushing, Proceedings of the World Congress on Engineering and Computer Science, San Francisco, USA, 2007

[15] A. A. N. Aljawi, M. Abd-Rabou, and S. Asiri, Finite Element And Experimental Analysis Of Square Tubes Under Dynamic Axial Crushing, European Congress on Computational Methods in Applied Sciences and Engineering, ECCOMAS 2004

[16] Milad Abbasi, Sekhar Reddy, All Ghafari-Nazari, Mohammad Fard, Multiobjective crashworthiness optimization of multi-cornered thin-walled sheet metal members. Thin-Walled Structures 89 (2015) 31-41

[17] H. Hesse, D.H.J.A. Lukaszewicz, F. Duddeck, A method to reduce design complexity of automotive composite structures with respect to crashworthiness. Composite Structures 129 (2015) 236-249

[18] J. Alexander, An approximate analysis of the collapse of thin cylindrical shells under axial loading. The Quarterly Journal of Mechanics and Applied Mathematics 13(1) (1960) 10-15

[19] T. Wierzbicki, W. Abramowicz, On the Crushing Mechanics of Thin-Walled Structures. Journal of Applied Mechanics 50(4a) (1983) 727-734

[20] W. Abramowicz, T. Wierzbicki, Axial Crushing of Multicorner Sheet Metal Columns. Journal of Applied Mechanics 56(1) (1989) 113-120

[21] W. Abramowicz, N. Jones, Dynamic progressive buckling of circular and square tubes. International Journal of Impact Engineering 4(4) (1986) 243-270

[22] M. Langseth, O.S. Hopperstad, Static and dynamic axial crushing of square thin-walled aluminium extrusions. International Journal of Impact Engineering 18(7-8) (1996) 949968 